\title{
Beszámoló a XI. Biometriai Konferencia Modellek népegészségügyi vizsgálatokban szekciójáról
}

\author{
Report of the section of Models in public health researches from the \\ XI. Biometry Conference
}

\author{
Szerző: Varsányi Péter $\bowtie$ \\ Egészségfejlesztés folyóirat
}

Beküldve: 2017.06.15.

doi: 10.24365/ef.v58i2.157

Kulcsszavak: Biometriai konferencia, Klinikai Biostatisztikai Társaság, népegészségügy

Keywords: Biometry Conference, Clinical Biostatistical Association, public health

2017. június 9-én, immár tizenegyedik alkalommal rendezték meg a Biometriai Konferenciát Budapesten. A rendezvény szervezői idén először, a népegészségügy területét érintő módszertani kérdésekkel kapcsolatos előadásoknak külön szekciót szenteltek. Az előadásokat igen nagy érdeklődés övezte, amelyet jól mutatott az utánuk kialakult szakmai vita, ahol a résztvevők a népegészségügyi és statisztikai megközelítések közötti különbségeket próbálták egymáshoz közelíteni.

A szekciót Vitrai József előadása nyitotta, amely a népegészségügyi szempontból kiemelkedő jelentő-

1. ábra: Vitrai József előadása

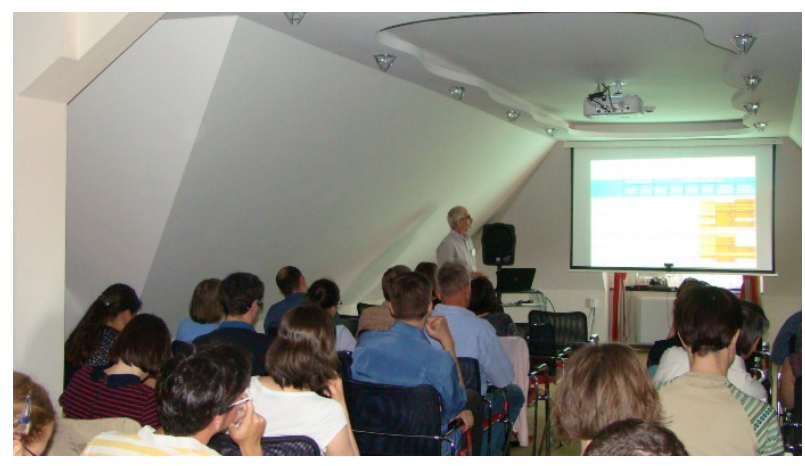

ségű akut miokardiális infarktus (AMI) ellátási egyenlőtlenségeinek járási vizsgálatára fókuszált, hangsúlyozottan a területi egyenlőtlenségek értelmezésén keresztül. (1. melléklet)

A második előadásban Varsányi Péter mutatott be egy, az iskoláskorúak hatásos viselkedésváltoztatását támogató, a hagyományos epidemiológiai vizsgálatokat rendszertudományi módszerekkel ötvöző kutatás eredményeit. (2. melléklet)

A következő prezentációban Bakacs Márta a 6-8 évesek tápláltsági állapotának és az egyes környezeti tényezőknek (pl. lakóhely, iskolai végzettség) az összefüggéseit vizsgáló nemzetközi kutatás magyarországi eredményeit ismertette. (3. melléklet)

Végezetül a szekciót Ferenci Tamás előadása zárta, amelyben a betegségek előfordulása időbeli változásának paraméteres és nem paraméteres regreszsziós modellezési lehetőségeit tekintette át, kiemelve a két módszer erősségeit és gyengeségeit. (4. melléklet)

A XI. Biometriai Konferencia teljes programja és az előadások absztraktjai itt érhetők el. 